Ігор Вікторович Рубан (доктор технічних наук, професор) ${ }^{1}$

Вадим Володимирович Тютюник (доктор технічних наук, с.н.с.) ${ }^{2}$

Ольга Олександрівна Тютюник (кандидат технічних наук, доцент) ${ }^{3}$

${ }^{1}$ Харківський національний університет радіоелектроніки, Харків, Украӥна

${ }^{2}$ Національний університет цивільного захисту Украӥни, Харків, Украӥна

${ }^{3}$ Харківський національний економічний університет імені Семена Кузнеця, Харків, Украйна

\title{
РОЗВИТОК НАУКОВО-ТЕХНІЧНИХ ОСНОВ ОПЕРАТИВНОГО ГЕОІНФОРМАЦІЙНОГО АКУСТИЧНОГО МОНІТОРИНГУ ДЖЕРЕЛ ТЕРОРИСТИЧНИХ НЕБЕЗПЕК
}

3 метою розвитку науково-технічних основ створення системи штучного інтелекту для моніторингу терористичних дій, в роботі представлені результати дослідження амплітудночастотних спектрів акустичної емісії (AE) процесу горіння целлюлозовмісних матеріалів (як одних з основних матеріалів, які використовуються для реалізації підпалів та нападів при організації терористичних дій у вигляді порушень правопорядку на локальній території) різного фізико-хімічного складу. Технічна реалізачія изього ефекту при розробиі автоматизованих пристроїв контролю акустичного простору, як складових системи оперативного геоінформаційного моніторингу за зоною терористичних дій, спрямована на раннє виявлення джерел терористичних небезпек для умов нормального функиіонування локальної території держави.

Ключові слова: джерела терористичних небезпек, терористичні дї, локальна територія, процес горіння, акустична емісія процесу горіння, целлюлозовмісні матеріали, характеристичні спектри, автоматизовані пристрої контролю акустичного простору, система штучного інтелекту, моніторинг терористичних дій.

\section{Ветуп}

Територія України, як система з територіальночасовим розподілом параметрів життєдіяльності рис. 1, у процесі свого функціонування та розвитку створює передумови для виникнення небезпек, які негативно впливають на стан природноекологічного, економіко-технічного та соціальнополітичного балансу на її території [1-3].

У відповідності до рис. 1, джерело інтегральної небезпеки в точці $\mathrm{A}(\mathrm{x}, \mathrm{y}, \mathrm{z})$ локальної території (як елементу функціональної поверхні, горизонтальні проекції якої співпадають 3 конфігурацією локальної території, а іiі випуклості відповідають рівням небезпеки в містах 3 конкретними географічними координатами) нелінійно об'єднує джерела природної небезпеки [4-6]:

$1^{\prime}$ - процеси у атмосфері;

$2^{\prime}$ - процеси у біосфері;

$3^{\prime}$ - процеси у літосфері;

4' - процеси у гідросфері; джерела техногенної небезпеки [7]:

$1^{\prime \prime}$ - аварії на промислових об'єктах i транспорті;

$$
2^{\prime \prime} \text { - вибухи; }
$$

$3^{\prime \prime}$ - пожежі;

4" - вивільнення інших видів енергії; джерела соціальної небезпеки [8]: $1^{\prime \prime \prime}$ - психологічні особливості особи й особливості виховання;

$2^{\prime \prime \prime}$ - несприятливе положення особи;

$3^{\prime \prime \prime}$ - соціальна несправедливість;

$4^{\prime \prime \prime}$ - напруженість у міжгрупових, міжконфесійних і міжнаціональних стосунках;

5"' - негативні соціальні процеси, що призводять до руйнування етичних засад, соціальної стійкості особи та законослухняності; джерела воєнної небезпеки [9, 10]:

$1^{\prime \prime \prime \prime}$ - наявність гострих суперечностей, розв'язання яких $є$ можливим лише із застосуванням воєнної сили;

$2^{\prime \prime \prime \prime}$ - наявність у однієї із сторін достатньої кількості військових сил і засобів для розв'язання суперечності на свою користь або здатність держави створити такі сили в перспективі;

$3^{\prime \prime \prime \prime}$ - наявність у лідерів або урядів політичної волі та рішучості піти на застосування сили, здатності використовувати збройні сили для вирішення можливого конфлікту;

$4^{\prime \prime \prime \prime}$ - наявність надійних союзників серед держав, їх коаліцій або інших суб'єктів військовополітичних відносин;

$5^{\prime \prime \prime \prime}$ - сприятливі геополітичні умови та реальна (або прогнозована) військово-політична обстановка для здійснення військових акцій. 


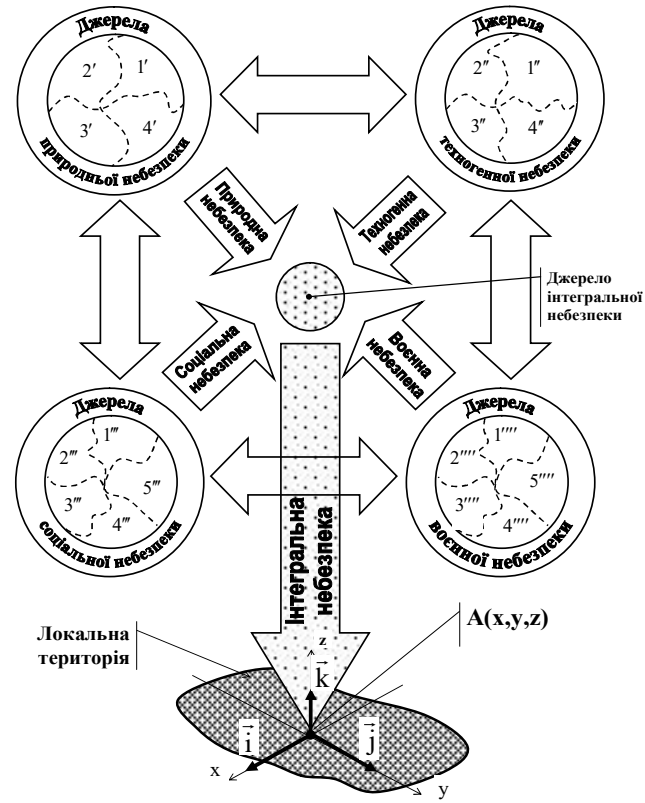

Рис. 1. Модельне представлення процесів зародження на локальній території джерел надзвичайних ситуацій різного походження
Постановка проблеми. В Україні для забезпечення реалізації державної політики у сфері цивільного захисту функціонує Єдина державна система цивільного захисту (СДСЦЗ), яка складається з функціональних і територіальних підсистем $[11,12]$ та спрямована на розв'язання питань забезпечення необхідного рівня безпеки життєдіяльності території держави лише в умовах, коли виникла НС.

При цьому, цілковито відкритими для держави залишаються проблемні питання реалізації, базуючись на уявленнях системного підходу та за даними рис. 2, в системі СДСЦЗ функції моніторингу та розробки ефективних управлінських рішень всіх локальних підсистем, спрямованих на попередження та локалізацію НС, в умовах зародження джерел небезпек різної природи $[13,14]$.

Це вказує на необхідність термінового розв'язання питань включення до складу СДСЦЗ інформаційно-аналітичної підсистеми управління процесами попередження й локалізації наслідків $\mathrm{HC}$.
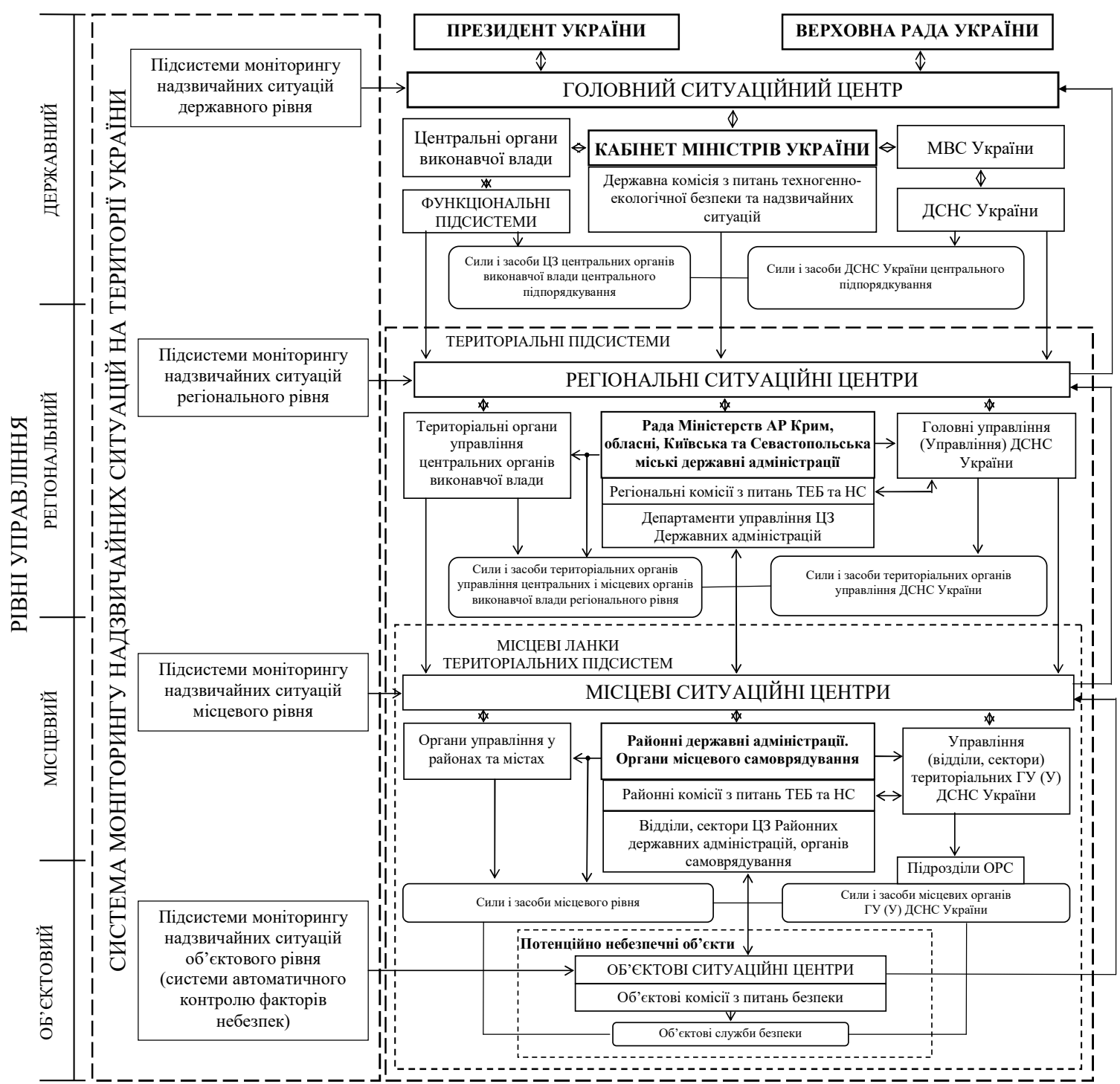

Рис. 2. Комплексна функціональна схема інформаційно-аналітичної підсистеми управління процесами запобігання, локалізації та ліквідації наслідків НС у Єдиній державній системі цивільного захисту 
Створення ефективної інформаційноаналітичної підсистеми управління процесами попередження й локалізації наслідків НC пропонується у відповідності за підходом, який розроблено у роботах $[15,16]$ та графічно представлено на рис. 2.

У цьому підході реалізовано комплексне включення в діючу систему СДСЦЗ по вертикалі від об'єктового до державного рівнів різних функціональних елементів територіальної підсистеми моніторингу $\mathrm{HC}$ та складових підсистеми ситуаційних центрів, які жорстко пов'язані між собою на інформаційному та виконавчому рівнях для прийняття відповідних антикризових рішень для розв'язання різних функціональних задач моніторингу, попередження та ліквідації НС природного, техногенного, соціального та воєнного характеру.

Одним 3 актуальних напрямків розробки у ЄДСЦЗ інформаційно-аналітичної підсистеми управління процесами запобігання, локалізації та ліквідації наслідків НC $€$ створення та забезпечення функціонування підсистем автоматизованого виявлення на локальній території джерел небезпек та телекомунікаційних мереж, а також центрів обробки даних, 3 функціями інформаційної підтримки прийняття антикризових рішень та їх виконання щодо мінімізації наслідків НC терористичного характеру.

Аналіз останніх досліджень i публікацій. Тероризм, у відповідності за даними рис. 3 , є суспільно-небезпечною діяльністю, яка полягає у свідомому, цілеспрямованому застосуванні насильства шляхом захоплення заручників, підпалів, убивств, тортур, залякування населення та органів влади або вчинення інших посягань на життя і здоров'я ні в чому не винних людей або погрози вчинення злочинних дій 3 метою досягнення злочинних цілей $[17,18]$.

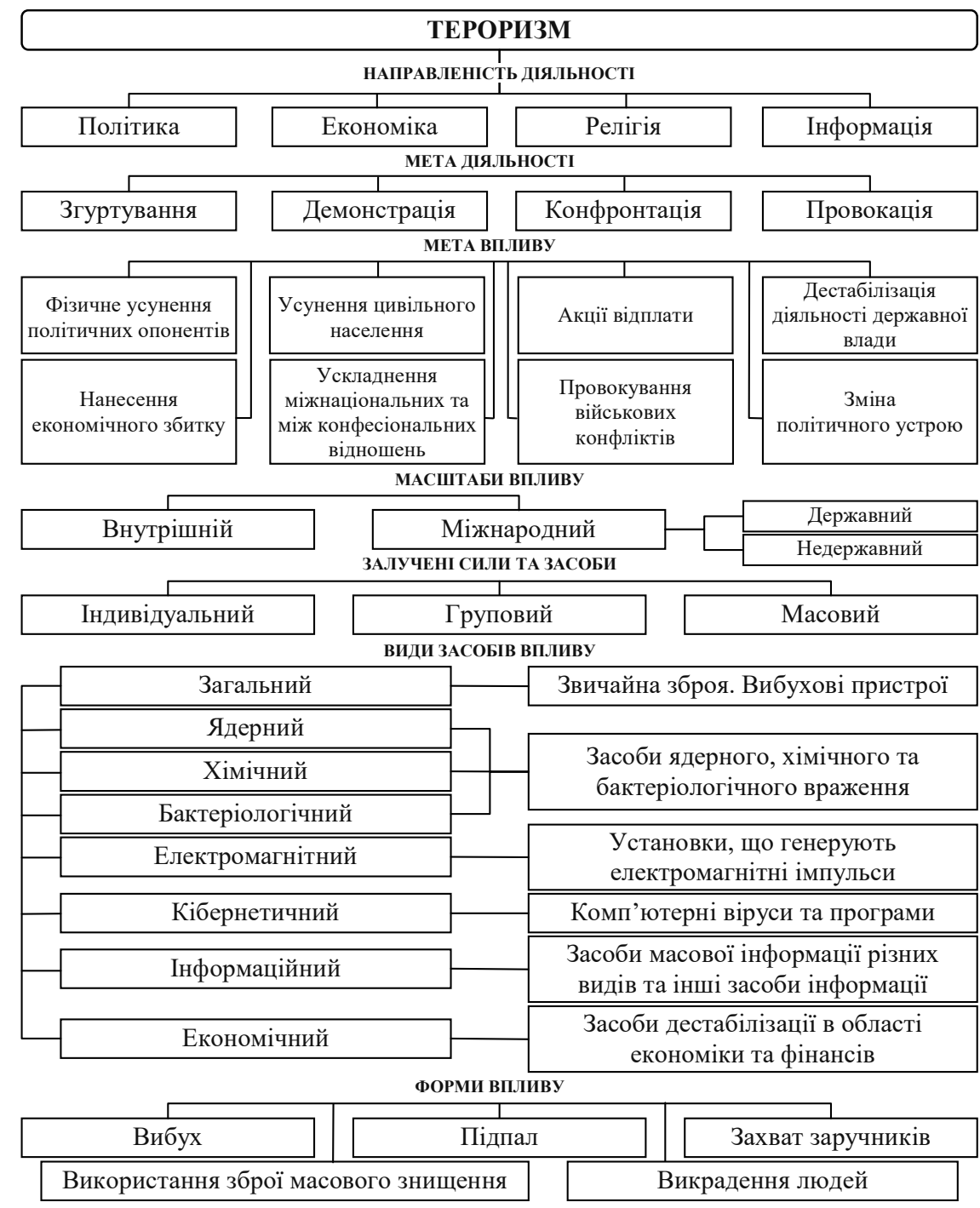

Рис. 3. Схема класифікації тероризму за видами небезпек

Терористична діяльність охоплює: 1) планування, організацію, підготовку i реалізацію терористичних актів; 2) підбурювання до вчинення терористичних актів, насильство над фізичними особами або організаціями, знищення матеріальних об'єктів у терористичних цілях; 3) організацію незаконних збройних формувань, злочинних угруповань (злочинних організацій), 
організованих злочинних груп для вчинення терористичних актів, так само як і участь в таких актах; 4) вербування, озброєння, підготовку та використання терористів; 5) пропаганду i поширення ідеології тероризму; 6) фінансування завідомо терористичних груп (організацій) або інше сприяння їм [19-27].

Одним 3 перспективних напрямків розв'язання проблеми автоматизованого раннього виявлення на локальній території терористичних дій $є$ контроль акустичного простору на контрольованій локальній території за допомогою безпілотних літальних апаратів (БПЛА) та наземних засобів безперервного отримання у реальному масштабі часу акустичної інформації про дії терористів та оперативного прогнозування розмірів зон $\mathrm{HC}$ терористичного характеру, а також обстановки в ній [28].

Метою статті $\epsilon$ розвиток науково-технічних основ створення геоінформаційної підсистеми автоматизованого контролю акустичного простору та виявлення на локальній території терористичних дій, а також оперативного прогнозування розмірів зони НС терористичного характеру та обстановки в ній, як складової інформаційно-аналітичної підсистеми управління процесами запобігання, локалізації та ліквідації наслідків НC Сдиної державної системи цивільного захисту.

\section{Виклад основного матеріалу дослідження}

Мета роботи досягається тим, що безперервний та тривалий у реальному масштабі часу оперативний моніторинг за зоною терористичних дій здійснюється за рахунок: а) сумісного об'єднання у систему моніторингу БПЛА та наземних пристроїв акустичного контролю факторів небезпек; б) оперативної доставки наземних мобільних пристроїв акустичного контролю у зону терористичних дій за допомогою БПЛА; в) створення в зоні терористичних дій та в iii околиці тимчасової (на період ліквідації небезпеки) контролюючої мережі 3 автоматизованих наземних мобільних пристроїв акустичного контролю; г) отримання й обробки інформації від наземних мобільних пристроїв акустичного контролю диспетчерським пунктом, який розташовано на наземній рухомій платформі [28-30].

Функціональну схему цієї підсистеми оперативного моніторингу за зоною терористичних дій, рівнем небезпеки в ній та прогнозування виникнення нових ризиків представлено на рис. 4.

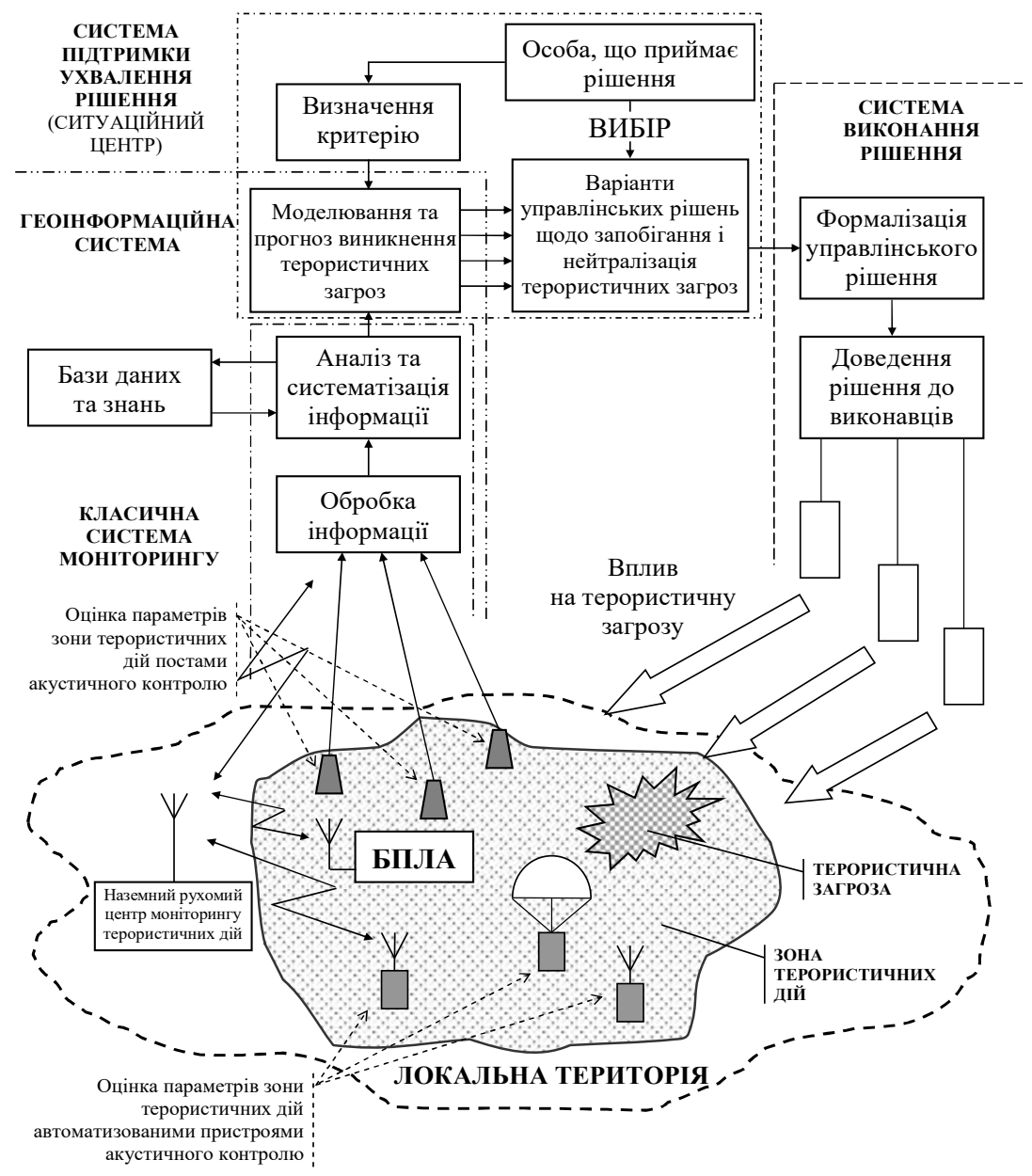

Рис. 4. Комплексна функціональна схема системи моніторингу зони терористичних дій засобами акустичного контролю 
Функціонування розробленої підсистеми оперативного акустичного моніторингу зони терористичних дій повинно здійснюватись у складі функціонуючої в Україні СДСЦЗ та в межах класичного контуру управління, який забезпечує: 1) збір, обробку та аналіз інформації; 2) моделювання НС терористичного характеру на території міста, регіону, держави; 3) розробку та ухвалення (в рамках ситуаційного центру) управлінських рішень щодо попередження та ліквідації НС терористичного характеру, а також мінімізації їх наслідків; 4) виконання рішень щодо попередження та ліквідації НС терористичного характеру, а також мінімізації їх наслідків [3, 14 $16]$.

У розробленій підсистемі отримання інформації про параметри зони терористичних дій здійснюється шляхом використання стаціонарних постів моніторингу акустичного простору та автоматизованими пристроями акустичного контролю, доставка яких у зону терористичних дій виконується БПЛА.

Отримана стаціонарними постами акустичного моніторингу первинна інформація про дії терористів на локальній території по кабелях передається до пристроїв другого рівня.

Первинну інформацію, що отримано автоматизованими пристроями акустичного контролю, які доставлено у зону терористичних дій за допомогою БПЛА, спочатку транслюють по радіоканалу до наземного рухомого центру моніторингу терористичних дій, де відбувається первинний аналіз та систематизація цієї інформації. Від наземного рухомого центру моніторингу терористичних дій інформація по радіоканалу транслюється також до пристроїв другого рівня.

Пристрої другого рівня призначені виконувати обробку отриманої інформації та представляти іiі у вигляді, необхідному для третього рівня.

Обробка отриманої інформації може виконуватися як в одному місці, так і на декількох, залежно від конкретної системи моніторингу та розмірів контрольованої нею локальної території. Оброблена інформація у відповідному вигляді надходить на третій рівень, де виконується іiі аналіз та систематизація даних, на основі чого робиться висновок про стан небезпеки локальної території. Особливо важливо для забезпечення швидкодії системи використання автоматизованих засобів обробки інформації, яке значно прискорить процеси на другому та третьому рівнях системи моніторингу, дозволить створити електронні, доступні в реальному масштабі часу, бази даних та знань. Використання відповідних математичних методів дозволить на основі отриманої інформації у відносно нетривалі терміни часу виконати моделювання небезпечної ситуації, прогнозування ii розвитку та рівня, відображати прогнозовану динаміку катастрофічних подій графічно (у тому числі з використанням мап).

Друга інформаційна підсистема $є$ системою підтримки ухвалення рішення. Особа, що приймає рішення (ОПР), визначає один або декілька критеріїв, відповідно до яких здійснюється прогностичне моделювання розвитку небезпеки та виробляються варіанти управлінських рішень, які обгрунтовані відповідними розрахунками. 3 набору варіантів управлінських рішень ОПР обирає один, або задає ще додаткові критерії, відповідно до яких виконується моделювання та розробка управлінських рішень, направлених на недопущення розвитку небезпеки до рівня катастрофи. Якщо ж катастрофи вже не уникнути, то розробка управлінських рішень направлена на мінімізацію наслідків від неї.

Затверджене ОПР рішення надходить до третьої системи - системи виконання рішення, де виконується його формалізація та доведення до виконавців. Зміни стану локальної території та зміни стану небезпеки на ній викликатимуть зміни у величинах вимірюваних параметрів, що фіксуються пристроями контролю. Подальше моделювання покаже ефективність виконання управлінського рішення - контур управління замкнувся.

Однією із форм впливу терористів на умови нормального функціонування локальної території, як природно-техногенно-соціальної системи, $є$ підпали (див. рис. 3), невід'ємною складовою яких $\epsilon$ хімічна реакція горіння, яка супроводжується виділенням значної кількості теплоти, диму і газів, а також випромінюванням світла. Процес горіння являє собою швидкий окислювально-відновний процес, при якому горюча речовина з'єднується 3 окислювачем і виділяється енергія та продукти розкладання [31-38].

Загальними закономірностями пожеж, відповідно до даних рис. 5, є: 1) горіння 3 виділенням тепла i продуктів повного та неповного згоряння; 2) массообмен, що виникає внаслідок утворення на пожежі конвекційних газових потоків, які забезпечують надходження свіжого повітря в зону горіння та відведення продуктів горіння 3 неї; 3) тепло, що виділяється в зоні горіння, передається в навколишнє середовище i частково витрачається на нагрів горючих речовин, будівельних конструкцій тощо i таким чином робить можливим самостійне розповсюдження процесу горіння.

Реалізація режиму раннього виявлення джерел загоряння для ефективної боротьби 3 терористичними діями свідчить про необхідність технічної реалізації нових фізико-технічних методів аналізу властивостей середовища загоряння, спрямованих на практично миттєвий контроль хвильових факторів небезпеки на етапі зародження та прояву джерел загорянь.

Практична значимість методу контролю хвильових факторів підтверджується тим, що вже відомі спроби ефективної технічної реалізації методу контролю пружних хвиль, які були викликані локальною динамічною перебудовою внутрішньої структури речовини (так званий процес акустичної емісіі) для раннього розпізнавання тріщин в металах і сплавах, для 
виявлення прихованих дефектів на стадії їх зародження, для дослідження корозії металів під напругою, вивчення кінетики розвитку тріщин в зварних швах, а також для дослідження акустич ських властивостей середовища загоряння [39-46].

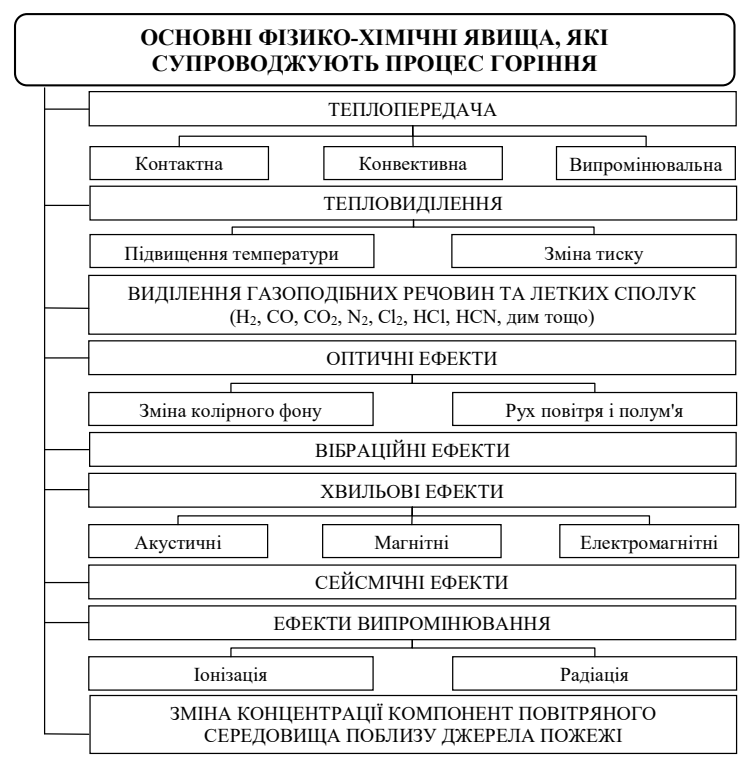

Рис. 5. Класифікація основних фізико-хімічних явищ, які супроводжують процес горіння

На підтвердження цих уявлень необхідно особливо відзначити, що в літературних джерелах [47-51] описані позитивні результати про розширення областей використання методу акустичної емісії, наведені експериментальні спроби виявити можливості цього методу для дослідження хімічних реакцій та фізико-хімічних процесів. Так, для встановлення акустичної емісії, що супроводжує процеси в гомогенних середовищах, були обрані і досліджені процеси розчинення сірчаної кислоти та етилового спирту у воді. В результаті розчинення рідини в рідині були зафіксовані характерні акустичні сигнали та відзначено два принципових моменти, які при сущі явищу виникнення акустичної емісії в фізикохімічних процесах: а) явище носить універсальний характер; б) імпульсний характер акустичної емісії при хімічних реакціях та фізико-хімічних процесах свідчать про те, що реакція відбувається в невеликому об'ємі і когерентно в часі в окремих ділянках системи, тому має місце колективна взаємодія субстратів.

Отримані результати дозволяють нам зробити припущення про перспективи створення пристрою акустичного контролю терористичних дій, в основу функціонування якого закладений принцип аналізу властивостей акустичних коливань, які випромінюються джерелом загоряння в результаті прояву ефекту акустичної емісії, як хвильового чинника на етапах прояву i розвитку пожежної небезпеки на локальній території у результаті підпалів, які скоюють терористи.

Фізико-хімічна суть прояву акустичної емісії при підпалі полягає в тому, що в процесі протікання окислювально-відновної реакції виникає спектр коливань, пов'язаних 3 виникненням i руйнуванням на молекулярному рівні напружень в кристалічній решітці матеріалу. При горінні же рідкої фази відбувається переміщення мас реагентів i продуктів та утворення бульбашок газу, що призводять до коливань навколишнього середовища об'єкта загоряння (кавітаційні явища). Чим більше молекул речовини задіяні в процесі протікання реакції, тим інтенсивніше горіння та могутніше випромінюється звукове коливання. Ефект акустичної емісії має місце на всіх стадіях горіння, поки $\epsilon$ деструкція матеріалу i температурний градієнт всередині вогнища горіння. При появі відкритого полум'я, коли реакція горіння переходить в стійку стадію, інтенсивність звукових коливань різко зростає. Це обумовлено при горінні твердих тіл посиленням ефектів деструкції і деформації матеріалу. Збільшення інтенсивності звукових коливань при горінні рідинно фазних матеріалів пов'язано з переходом в стадію кипіння поверхневого шару на границі полум'я. При цьому необхідно відзначити, що i саме полум'я викликає значні коливання повітря за рахунок нерівномірності течії реакції горіння. Крім того, виділення газових складових при горінні як твердих, так і рідких речовин, також призводить до локальних коливань повітря в місці виходу газу із зони горіння.

Цей ефект генерації акустичних коливань в процесі прояву й розвитку пожежної небезпеки (як і при протіканні інших фізико-хімічних процесів) випливає з аналізу об'єднаного рівняння першого $\mathrm{i}$ другого законів термодинаміки [52-54]:

$$
\mathrm{dG}=\mathrm{pdV}-\mathrm{TdS}+\sum \mu_{\mathrm{i}} \mathrm{dn}_{\mathrm{i}}+\varphi \mathrm{dq}+\sigma \mathrm{ds}+\ldots,
$$

де $\mathrm{G}$ - енергія Гіббса; $\mathrm{S}$ - ентропія; T температура; V - об'єм; p - тиск; $\sigma-$ поверхнева напруга (поверхнева напруга для твердих тіл); s - площа поверхні; $\mu_{\mathrm{i}}-$ хімічний потенціал i-го компоненту; $\mathrm{n}_{\mathrm{i}}$ - кількість молей iго компоненту; $\varphi$ - електричний потенціал; q електричний заряд.

За аналогією 3 відомими процесами перетворення хімічної енергії в електричну ( $\varphi d q)$, теплову ( $\mathrm{TdS})$ та електромагнітну, має відбуватися безпосереднє перетворення іiі в механічну (pdV). Оскільки, у всій системі одинична зміна обсягу у вигляді єдиного імпульсу не може статися в силу фізичних властивостей, то в системі будуть порушуватися акустичні коливання.

У зв'язку з тим, що імпульсний характер акустичної емісії характеризується імпульсами тривалістю $10^{-8}-10^{-4}$ с (час елементарного акту передачі $\overline{\mathrm{e}}$ в хімічній реакції), а енергія окремого імпульсу - від $10^{-9}$ до $10^{-5}$ Дж, то частотний спектр акустичної емісії лежить в широких межах від області інфразвуку і частот чутного звуку до десятків і сотень МГц, інтенсивність імпульсів акустичної емісії залежить від обсягу зони, в якій 
речовина піддається деструкції, а також від зміни обсягу продуктів реакції.

Значення амплітуди механічних коливань (звукові хвилі) в твердих тілах при хімічних реакціях, згідно, знаходяться в межах від $1 \cdot 10^{-4}$ до 5 мм.

Характерний частотний діапазон хімічних реакцій, відповідно до даних рис. 6 , виходить за області частотних діапазонів, які характерні основним видам життєдіяльності території України.

Отже, можливо виділити характеристичний для джерела загоряння спектр випромінюваних звукових хвиль на фоні загального звукового випромінювання [55-57].

Дослідження, які були проведені у роботах [5860], лягли в основу подальших науково-технічних досліджень спектральних характеристик горіння різного роду матеріалів в умовах реалізації підпалів при організації терористичних дій у вигляді порушень правопорядку на локальній території, 3 метою розробки автоматизованих пристроїв контролю акустичного простору, як складових системи оперативного моніторингу за зоною терористичних дій, рівнем небезпеки в ній та прогнозування виникнення нових ризиків.

Згідно $з$ даними рис. 7, ефект акустичної емісії має місце на всіх стадіях горіння. Так, акустичні хвилі будуть випромінюватися протягом усіх стадій горіння, поки $є$ деструкція матеріалу та температурний градієнт всередині джерела горіння. Стадії горіння целюлозовмісних або полімерних матеріалів можливо описати у вигляді рівнянь (2-6) хімічної реакції:

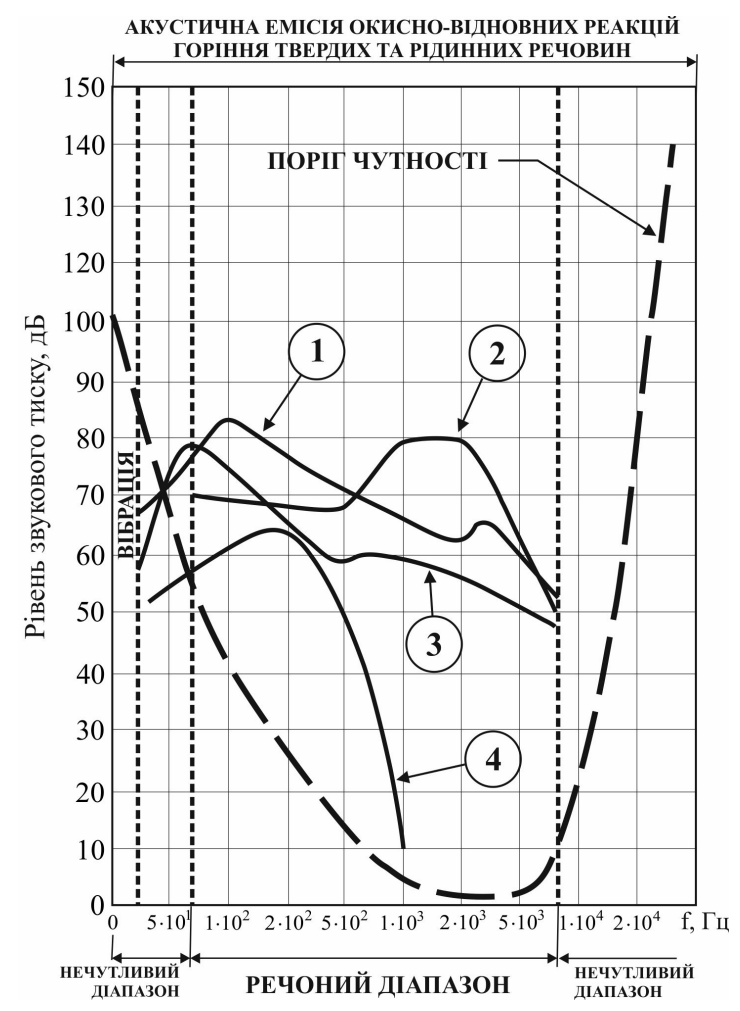

Рис. 6. Спектральні характеристики основних перешкод для функціонування автоматизованих пристроїв контролю акустичного простору у зоні

терористичних дій, які виникають у процесі життєдіяльності локальної території: 1 - транспортні потоки (на відстані 7,5 м) при інтенсивності руху 250

автомобілів за годину; 2 - потяг (на відстані 25 м)

при швидкості руху 160 км/год; 3 - місто; 4 -

гелікоптер (на відстані 150 м) при швидкості 190 км/год

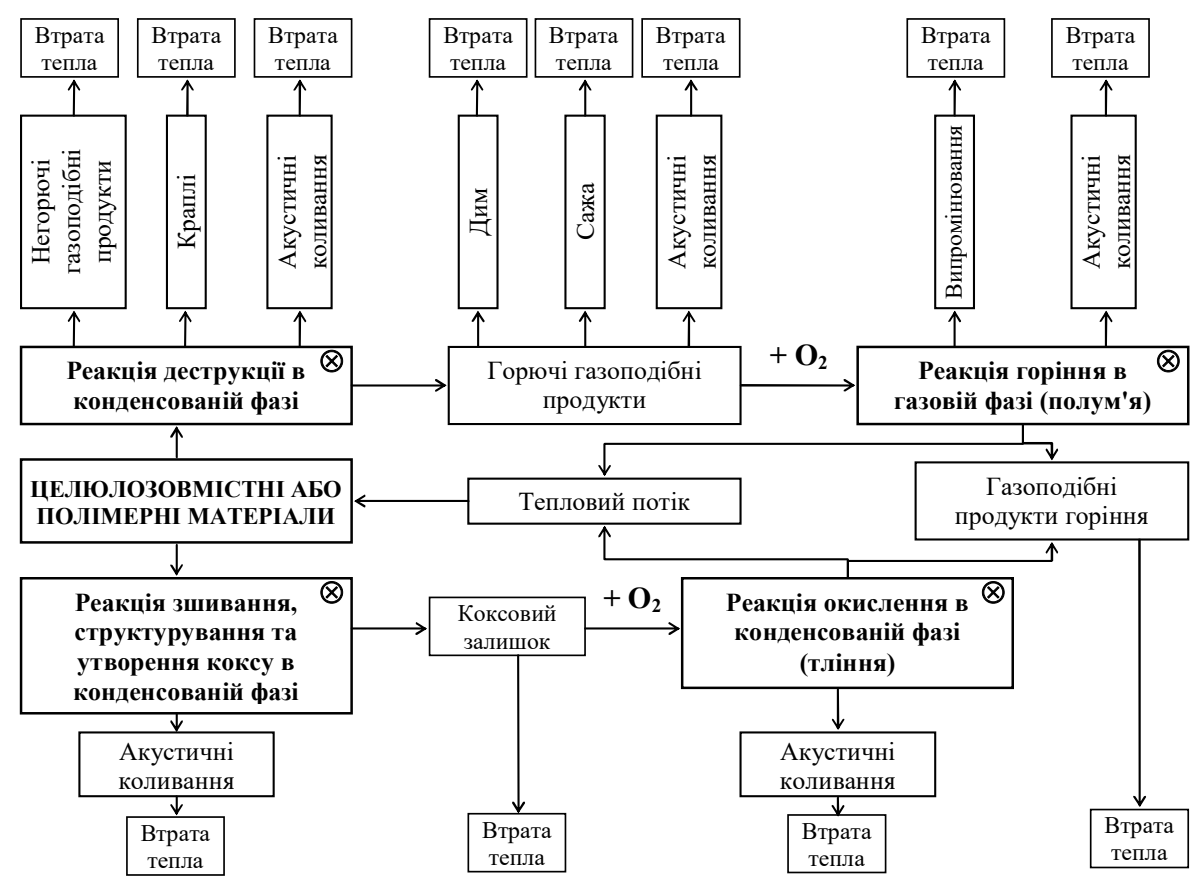

Рис. 7. Схема горіння целюлозовмісних або полімерних матеріалів та прояву ефекту акустичної емісії на стадіях горіння. $\otimes$ - найхарактерніші стадії акустичної емісії при фізико-хімічних перетвореннях 
а) недолік $\mathrm{O}_{2}$ (піроліз):

$$
\mathrm{nC}_{6} \mathrm{H}_{10} \mathrm{O}_{5(\mathrm{~T})}+\mathrm{nO}_{2(\Gamma)} \stackrel{\mathrm{t}}{\longrightarrow} 4 \mathrm{nC}_{(\mathrm{T})} \downarrow+2 \mathrm{nCO}_{(\Gamma)} \uparrow+5 \mathrm{nH}_{2} \mathrm{O}_{(\Gamma)} \uparrow
$$

б) надлишок $\mathrm{O}_{2}$ :

$$
\begin{gathered}
\mathrm{nC}_{6} \mathrm{H}_{10} \mathrm{O}_{5(\mathrm{~T})}+3 \mathrm{nO}_{2(\Gamma)} \stackrel{\mathrm{t}}{\longrightarrow} 6 \mathrm{nCO}_{(\Gamma)} \uparrow+5 \mathrm{nH}_{2} \mathrm{O}_{(\Gamma)} \uparrow \\
\mathrm{nC}_{6} \mathrm{H}_{10} \mathrm{O}_{5(\mathrm{~T})}+4,5 \mathrm{nO}_{2(\Gamma)} \stackrel{\mathrm{t}}{\longrightarrow} 3 \mathrm{nCO}_{(\Gamma)} \uparrow+3 \mathrm{nCO}_{2(\Gamma)} \uparrow+5 \mathrm{nH}_{2} \mathrm{O}_{(\Gamma)} \uparrow \\
\mathrm{nC}_{6} \mathrm{H}_{10} \mathrm{O}_{5(\mathrm{~T})}+6 \mathrm{nO}_{2(\Gamma)} \stackrel{\mathrm{t}}{\longrightarrow} 6 \mathrm{nCO}_{2(\Gamma)} \uparrow+5 \mathrm{nH}_{2} \mathrm{O}_{(\Gamma)} \uparrow
\end{gathered}
$$

в) у випадку утворення СО можливе подальше його горіння в умовах контакту у об'ємі полум'я 3 киснем:

$$
\mathrm{CO} \uparrow+\mathrm{O}_{2} \uparrow \stackrel{\mathrm{t}}{\longrightarrow} \mathrm{CO}_{2} \uparrow
$$

Для проведення лабораторних досліджень використано лабораторну установку, структурну схему та фото якої представлено на рис. 8 та 9.

Результати експериментів представлені на рис. 10-14 в вигляді амплітудно-частотних акустичних спектрів для деревини (сосна) та інших целлюлозовмісних матеріалів (бинт, картон, папір, вата).

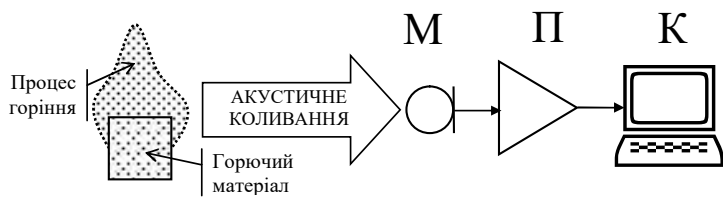

Рис. 8. Схема лабораторної установки для дослідження умов прояву ефекту акустичної емісії на стадіях горіння різних горючих матеріалів

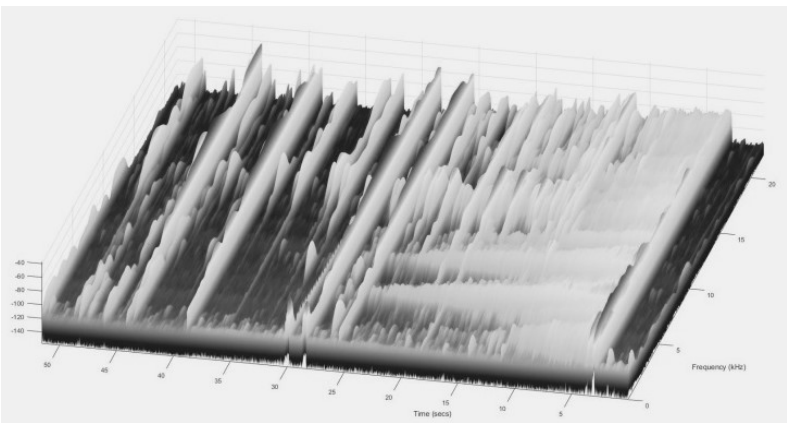

Рис. 10. Акустичні спектри від часу горіння зразка дерева (сосна) після фільтрації від фонових перешкод

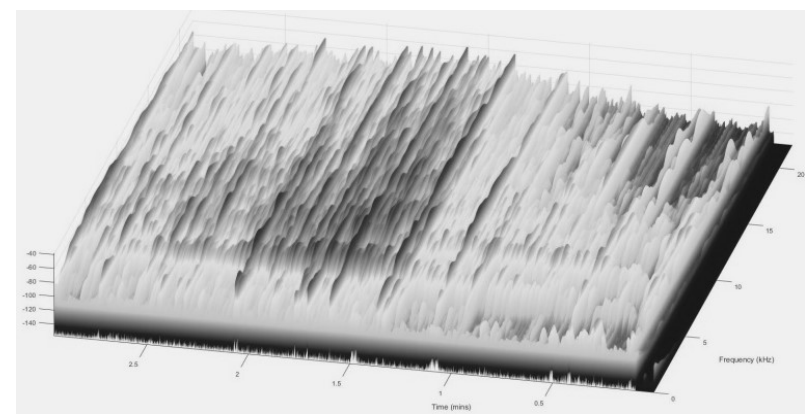

Рис. 12. Акустичні спектри від часу горіння зразка картону після фільтрації від фонових перешкод

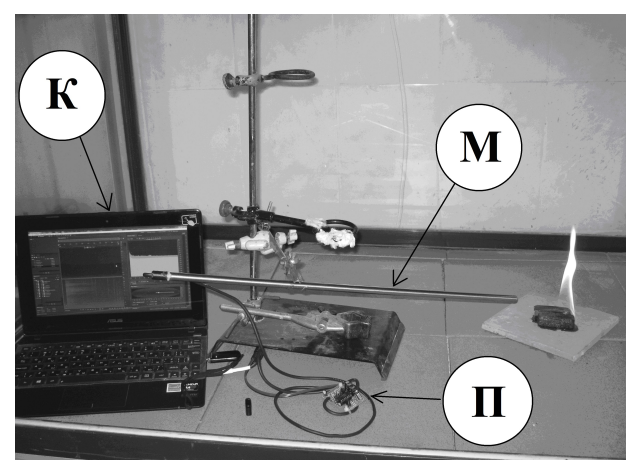

Рис. 9. Фото лабораторної установки для дослідження умов прояву ефекту акустичної емісії на стадіях горіння різних горючих матеріалів: $\mathrm{M}-$ мікрофон; П - підсилювач; К - комп'ютер

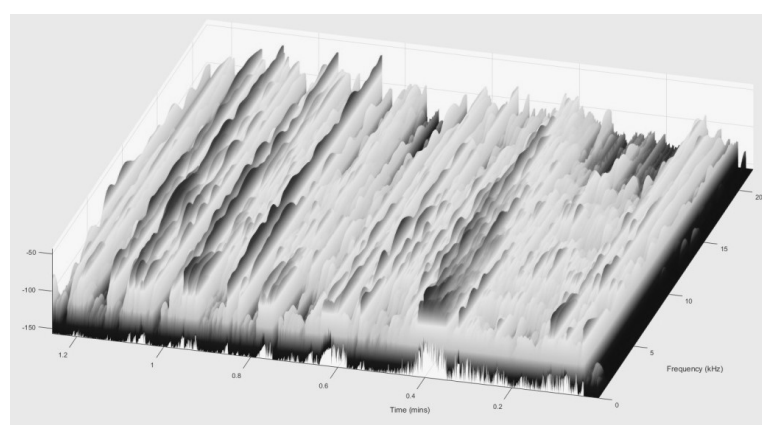

Рис. 11. Акустичні спектри від часу горіння зразка бумаги після фільтрації від фонових перешкод

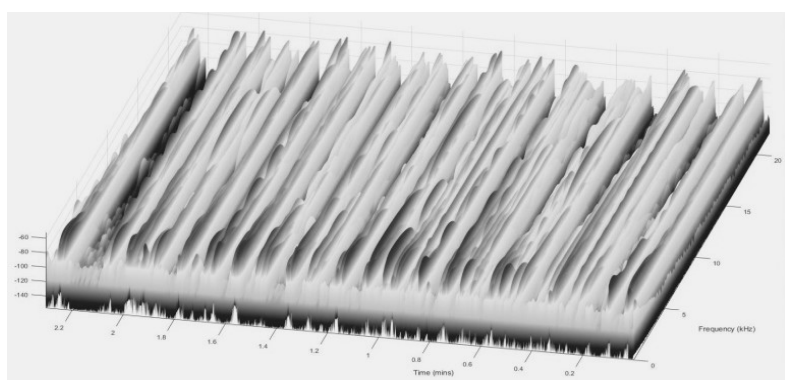

Рис. 13. Акустичні спектри від часу горіння зразка вати після фільтрації від фонових перешкод 


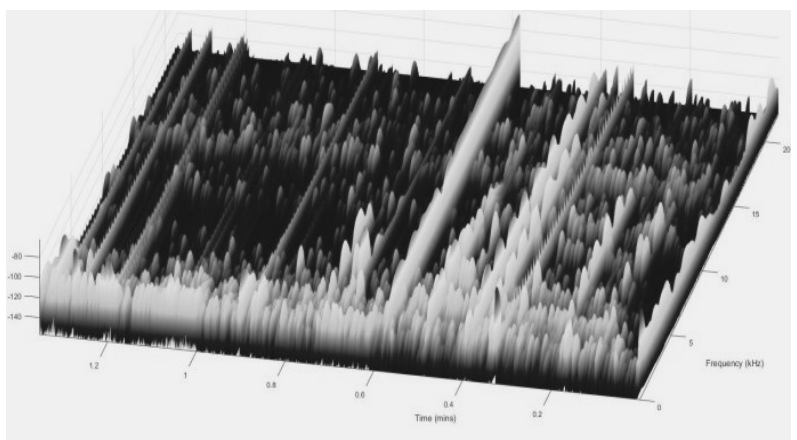

Рис. 14. Акустичні спектри від часу горіння зразка бинту після фільтрації від фонових перешкод

Обробка цих спектрів в єдиних координатах $\mathrm{P}_{\min } / \mathrm{P}_{\mathrm{a}}$ (відносна амплітуда сигналу) від $\mathrm{f}$ (частота сигналу) показала задовільну збіжність пікових амплітуд досліджуваних зразків в різних діапазонах частот (5 Гц - 25 кГц). Незбіжність для деяких діапазонів частот пояснюється різним вмістом целюлози в зразках, а також специфікою самого процесу високотемпературного окислення, який істотно залежить від домішкових компонент матеріалу та структури досліджуваних зразків.

Узагальнену гістограму розподілу пікових амплітуд спектрів акустичної емісії для досліджених матеріалів (дослідження проведені на трьох зразках кожного типу целлюлозовмісного матеріалу) представлено на рис. 15. Усередненні для кожного типу целлюлозовмісного матеріалу амплітудно-частотних характеристики спектрів акустичної емісії при їх горінні представлені на рис. 16.

Як видно 3 даних рис. 14, процес горіння досліджених матеріалів характеризується високою щільністю максимальних амплітуд в областях частот від 5 до 200 Гц і від 400 Гц до 25кГц. Максимальна збіжність амплітуд найбільш характерна для діапазону частот $1-11$ кГц.

Наведені на рис. 14 та 15 результати досліджень показали, що процес горіння целлюлозовмісних матеріалів характеризується наявністю спектрів акустичної емісії в низькочастотних (від 0 до 1000 Гц) так і в високочастотних (від 1 до 25,4 кГц) областях. Амплітудна характеристика максимальна для вати $\left(\mathrm{P}_{\min } / \mathrm{P}_{\mathrm{a}}=1,92\right.$, де $\left.\mathrm{P}_{\min }=115 \mathrm{~dB}\right)$ в порівнянні 3 іншими матеріалами $\left(\mathrm{P}_{\min } / \mathrm{P}_{\mathrm{a}}=1,00 \div 1,40\right)$ як для низькочастотних, так i для високочастотних областей.

Таким чином, виконані дослідження особливостей процесу горіння різних целлюлозовмісних матеріалів методом акустичної емісії однозначно вказують на високу ефективність встановлення фактів можливих підпалів при організації терористичних дій у вигляді порушень правопорядку на локальній території.

\section{Висновки й перспективи подальших досліджень}

Викладені основні принципи створення інформаційно-аналітичної підсистеми управління процесами попередження й локалізації наслідків терористичних дій у СДСЦЗ:

1. Тероризм, як суспільно-небезпечна діяльність, полягає у свідомому, цілеспрямованому застосуванні насильства шляхом захоплення заручників, підпалів, убивств, тортур, залякування населення та органів влади або вчинення інших посягань на життя і здоров'я ні в чому не винних людей або погрози вчинення злочинних дій 3 метою досягнення злочинних цілей. Системний підхід i принцип оцінки небезпеки життєдіяльності території держави в умовах виникнення терористичних загроз повинні базуватися на уявленнях про локальну територію 3 динамічними розмірами, які змінюються від точки простору (пікселю) до рівня об'єкта, міста, регіону та вище. Для оцінки небезпеки локальної території в роботі обгрунтовано використання функціональної поверхні, горизонтальні проекції якої співпадають 3 конфігурацією локальної території, а іiі випуклості відповідають рівням небезпеки в містах 3 конкретними географічними координатами.

2. Основу Єдиної системи цивільного захисту держави в умовах виникнення терористичних загроз становить класичний контур управління, який забезпечує: збір, обробку та аналіз інформації; моделювання розвитку обстановки на об'єкті управління та розвитку рівня терористичних загроз на території міста, регіону, держави; розробку та ухвалення управлінських рішень щодо попередження та ліквідації терористичних дій, a також мінімізації їх наслідків; виконання рішень щодо попередження та ліквідації терористичних дій, а також мінімізації їх наслідків.

3. Створення ефективної інформаційноаналітичної системи управління процесами попередження й локалізації наслідків терористичних дій шляхом комплексного включення в діючу систему СДСЦЗ по вертикалі від об'єктового до державного рівнів різних функціональних елементів територіальної системи моніторингу НС та складових системи ситуаційних центрів, які жорстко пов’язані між собою на інформаційному та виконавчому рівнях для прийняття відповідних антикризових рішень, для розв'язання різних функціональних задач моніторингу, попередження та ліквідації терористичних дій. 
4.3 метою забезпечення безперервного та тривалого у реальному масштабі часу оперативного моніторингу за зоною терористичних дій розроблено функціональну схему системи оперативного моніторингу за зоною терористичних дій, рівнем небезпеки в ній та прогнозування виникнення нових ризиків, яка характеризується тим, що в системі: а) сумісно застосовуються БПЛА та наземні пристрої контролю факторів небезпек; б) оперативна доставка наземних мобільних пристроїв контролю у зону терористичних дій здійснюється за допомогою БПЛА; в) проводиться створення в зоні терористичних дій та в ії околиці тимчасової (на період ліквідації небезпеки) контролюючої мережі 3 автоматизованих наземних мобільних пристроїв контролю; г) отримання й обробка інформації від наземних мобільних пристроїв контролю проводиться диспетчерським пунктом, який розташовано на наземній рухомій платформі.

5. Однією із небезпечних форм впливу терористів на умови нормального функціонування локальної території, як природно-техногенносоціальної системи, є підпали. Реалізація режиму раннього виявлення джерел загоряння для ефективної боротьби 3 терористичними діями свідчить про необхідність технічної реалізації пристроїв контролю за зоною терористичних дій на нових фізико-технічних методах аналізу

\section{Лimepamypa}

1. Тютюник В.В., Чорногор Л.Ф., К Калугін В.Д. Системний підхід до оцінки небезпеки життєдіяльності при територіально часовому розподілі енергії джерел надзвичайних ситуацій. Проблеми надзвичайних ситуацій. Харків: Національний університет цивільного захисту України. 2011. Вип. 14. С. 171-194. 2. Калугін В.Д., Тютюник В.В., Торногор Л.Ф., Шевченко P.I. Системний підхід до оцінки ризиків надзвичайних ситуацій в Україні. ВосточноЕвропейский журнал передовых технологий. 2012. 1/6 (55). С. 59-70. 3. Андронов В.А., Дівізінюк М.М., Калугін В.Д., Тютюник В.В. Науково-конструкторські основи створення комплексної системи моніторингу надзвичайних ситуацій в Україні. Монографія. Харків: Національний університет цивільного захисту України, 2016. 319 с. 4. Черногор Л.Ф. Физика и экология катастроф. Харьков: Харьковский национальный университет имени В.Н. Каразина. 2012. 556 с. 5. Черногор Л.Ф. О нелинейности в природе и науке. Харьков: Харьковский национальный университет имени В.Н. Каразина. 2008. 528 с. 6. Тютюник В.В., Калугін В.Д. Аналіз факторів, які провокують виникнення надзвичайних ситуацій природного характеру. Системи обробки інформачіï. Харків: Харківський університет Повітряних Сил імені Івана Кожедуба. 2011. Вип.4(94). С. 280-284. 7. Биченок М.М., Трофимчук О.М. Проблеми природно-техногенної безпеки в Україні. Київ: РНБОУ, 2002. 153 с. 8. Михайлов Л.А., Соломин В.П. Чрезвычайные ситуации природного, техногенного и социального характера и защита от них. СПб.: Питер, 2008. 235 с. 9. Про національну безпеку України: Закон України від 21 червня 2018 року № 2469-VIII [Електронний ресурс]. Режим доступу: http://zakon.rada.gov.ua/laws/show/2469-19

10. Ліпкан В.А. Національна безпека України [Електронний ресурс]. Режим доступу: властивостей середовища загоряння, спрямованих на практично миттєвому контролі хвильових факторів небезпеки на етапі зародження та прояву джерел загорянь. Запропоновано контроль джерела загоряння проводити по спектральним характеристикам акустичних коливань, що генеруються джерелом загоряння в результаті прояву ефекту акустичної емісії при протіканні окисно-відновної реакції горіння різних (твердих, рідких та газоподібних) речовин і матеріалів.
6. Прикладні результати
проведених досліджень: а) розроблено та створено установку для вимірювання спектрів акустичної емісії 3 високою чутливістю, для широкого частотного діапазону $\quad(5 Г ц-25 \kappa Г ц) ; \quad$ б) розроблено комплексну методику та алгоритм фільтрації спектру фону із загальної акустичної спектрограми для визначення характеристичних гармонік прояви реакції горіння; в) показано стійку залежність амплітудно-частотних характеристик акустичної емісії процесу горіння від природи і хімічного складу целлюлозовмісних матеріалів; г) виконані дослідження особливостей процесу горіння різних целлюлозовмісних матеріалів методом акустичної емісії однозначно вказують на високу ефективність встановлення фактів можливих підпалів при організації терористичних дій у вигляді порушень правопорядку на локальній території.

http://westudents.com.ua/knigi/368-natsonalna-bezpekaukrani-lpkan-va.html 11. Кодекс цивільного захисту України від 2 жовтня 2012 року № 5403-VI. Голос Украйни. 2012. листопад (№ 220(5470)). С. 4-20. 12. Постанова Кабінету Міністрів України від 9 січня 2014 року № 11 «Про затвердження Положення про Єдину державну систему цивільного захисту» [Електронний ресурс]. Режим доступу: http://zakon5.rada.gov.ua/laws/show/11-2014-\%D0\%BF

13. Розпорядження Кабінету Міністрів України від 25 січня 2017 року № 61-р. «Про схвалення Стратегії реформування системи Державної служби України 3 надзвичайних ситуацій» [Електронний ресурс]. Режим доступу: http://zakon5.rada.gov.ua/laws/show/61-2017$\% D 1 \% 80$ 14. Калугін В.Д., Чорногор Л.Ф., Шевченко Р.І. Розробка науковотехнічних основ для створення системи моніторингу, попередження та ліквідації надзвичайних ситуацій природного та техногенного характеру та забезпечення екологічної безпеки. Системи обробки інформації. Харків: Харківський університет Повітряних Сил імені Івана Кожедуба. 2013. Вип.9(116). С. 204-216. 15. Тютюник В.В., Калугін В.Д., Писклакова О.О. Основоположні принципи створення у Єдиній державній системі цивільного захисту інформаційноаналітичної підсистеми управління процесами попередження й локалізації наслідків надзвичайних ситуацій. Системи управління, навігащії та зв'язку. Полтава: Полтавський національний технічний університет імені Юрія Кондратюка. 2018. №4(50). С. 168-177. 16. Тютюник В.В., Калугін В.Д., Писклакова О.О. Оцінка умов створення у Єдиній державній системі цивільного захисту інформаційноаналітичної підсистеми управління процесами попередження й локалізації наслідків надзвичайних ситуацій на основі аналізу динаміки прояву небезпек на території України. Наукове видання "Комунальне 
господарство міст. Науково-технічний збірник. Серія: «Технічні науки та архітектура». Харків: Харківський національний університет міського господарства імені О.М. Бекетова. 2019. №1(147). $\quad$ С. 66-82. 17. Про боротьбу з тероризмом: Закон України від 20 березня 2003 року № 638-IV [Електронний ресурс]. Режим доступу: $\quad$ https://zakon.rada.gov.ua/laws/show/638-15 18. Кримінальний кодекс України від 5 квітня 2001 року № 2341-III [Електронний ресурс]. Режим доступу: https://zakon.rada.gov.ua/laws/show/2341-14\#n1707

19. Авдеев Ю.И. Терроризм как социальнополитическое явление. Под ред. Е.И. Степанова. М.: Культура, 1997. 423 с. 20. Заявление «Группы восьми» об укреплении программы $\mathrm{OOH}$ по борьбе с терроризмом [Электронный ресурс]. Режим доступа: http://www.krernlm.rn/mterdocs/2006/07/16/2037

21. Доклад Министерства обороны США 1997 г. об антитеррористической деятельности. Responding of Defense's 1997. Annual Defense Report [Электронный pecypc]. Режим доступа: http://www.terrorism.com/terrorism/Responding. shtml 22. Доклад Генерального секретаря Кофи Аннана от 3 мая 2006 г. «Единство в борьбе с терроризмом: рекомендации по глобальной контртеррористической стратегии». Режим доступа: http://www.un.org/russian/unitingagainstterrorism/report.ht $m l$ 23. Грачев С.И. Терроризм. Вопросы теории. Монография. Н. Новгород: Изд-во ННГУ им. Н.И. Лобачевского， 2007. 269 с. 24. Васильев Н.Т., Тарасов М.Ю., Поклонский Д.Л. Биологический терроризм: прошлое, настоящее, будущее. Химическая $и$ биологическая безопасность. 2002. № 6. С. 3-10. 25. Татаринов В.В. Радиационный, химический и биологический терроризм. Интернет-журнал "Технологии техносферной безопасности". 2012. Вып.3(43) [Электронный ресурс]. Режим доступа: http://ipb.mos.ru/ttb 26. Антипенко В.Ф. Борьба с современным терроризмом: междунар.-правовые подходы. Институт государства и права им. В.М. Корецкого. Киев: Юнона-М, 2002722 с. 27. Tucker J.B. Historical trends related to bioterrorism: an empirical analysis. Emerg. Infec. Disease. 1999. V.5. № 4. Р. 498-504. 28. Тютюник В.В., Калугін В.Д., Чорногор Л.Ф., Шевченко Р.І. Розробка науковотехнічних основ системи моніторингу зони надзвичайної ситуації, яка включає доставку автоматизованих пристроїв контролю повітряними безпілотними засобами. Наука $i$ техніка Повітряних Сил Збройних Сил Украйни. Харків: Харківський університет Повітряних Сил імені Івана Кожедуба. 2014. №3(16). С. 41-44. 29. Тютюник В.В. Калугін В.Д., Іванець Г.В., Іванець М.Г., Захарченко Ю.В. Оцінка ефективності покриття території надзвичайної ситуації за допомогою автоматизованих пристроїв контролю небезпечних факторів при їх розкиданні із зависаючого над точкою скидання безпілотного літального апарату. Техногенно-екологічна безпека та иивільний захист. Київ: Інститут геохімії навколишнього середовища НАН України. 2016. Вип.10. С. 34-43. 30. Іванець Г.В., Тютюник В.В., Калугін В.Д., Захарченко Ю.В. Алгоритм оцінки ефективності покриття території надзвичайної ситуації автоматизованими пристроями контролю небезпечних факторів при їх розкиданні з безпілотного літального апарату в умовах нестабільностей повітряного середовища. Проблеми надзвичайних ситуацій. Харків: Національний університет цивільного захисту України. 2017. Вип.25. С. $45-56 . \quad$ 31. Абдурагимов И.М., Говоров В.Ю., Макаров В.Е. Физико-химические основы развития и тушения пожаров. М.: ВИПТШ МВД СССР, 1980. 255 с. 32. Померанцев В.В. Основы практической теории горения. Л.: Энергоатомиздат, 1986. 312 с. 33. Пожаровзрывоопасность веществ и материалов и средства их тушения. Справочник. Книга 1-2. Под ред. Баратова А.Н. и Корольченка А.Я. М.: Химия, 1990. 495 с.+384 с. 34. Киселев Я.С. Физические модели горения в системе предупреждения пожаров. С.П.: СПУ МВД России, 2000. 264 с. 35. Єлагін Г.І., Шкарабура М.Г., Кришталь М.А., Тищенко О.М. Основи теорії розвитку і припинення горіння. Черкаси: Черкаський інститут пожежної безпеки, 2001. 448 с. 36. Тарахно О.В. Теоретичні основи пожежовибухонебезпеки. Харків: Академія цивільного захисту України, 2006. 395 с. 37. Корольченко А.Я. Процессы горения и взрыва. М.: Пожнаука, 2007. 266 с. 38. Кусковець С.Л., Ш Шаталов О.С., Турченюк В.О. Основи теорії горіння та вибуху. Рівне: Національний університет водного господарства та природокористування, 2012. 374 с. 39. Грешников В.А., Дробот Ю.Б. Акустическая эмиссия. М.: Изд-во стандартов, 1976. 276 c. 40. Eitzen D.G., H.N.G. Wadley Acoustic Emission: Establishing the Fundamentals. Journal of Research of the National Bureau of Standards. 1984. Vol.89. №1. January-February. P. 75-100. 41. Grosshandler W.L., Jackson M. Acoustic Emission of Structural Materials Exposed to Open Flames. Fire Safety Journal. 1994. Vol.22. P. 209-228. 42. Членов А.Н. Ультразвуковые охранные и охранно-пожарные извещатели для закрытых помещений. Cистемы безопасности, связи и телекоммуникаций. март-апрель. М., 1999. С. 25-27. 43. Пузач С.В., Поляков Ю.А. Обоснование возможности раннего обнаружения возгорания в помещении с помощью датчиков давления. Проблемы безопасности при чрезвычайных ситуачиях. 1999. Вып.3. С. 53-56. 44. Асминг В.Э., Евтюгина 3.А., Виноградов Ю.А., Федоров А.В. Анализ инфразвуковых сигналов, генерируемых техногенными источниками. Вестник МГТУ. 2009. т.12. №2. С. 300 $307 . \quad 45$. Климчук Е.Г., Парахонский А.Л. Акустическая диагностика процессов «твердофазного горения» смесей органических кристаллов. Ученые записки физического факультета. 2014. №6. С. 1463221-146322-5. 46. Беликов В.Т., Рывкин Д.Г. Использование результатов наблюдений акустической эмиссии для изучения структурных характеристик твердого тела. Акустический журнал. 2015. т.61. №5. С. 622-630. 47. Смирнов А.Н. Генерация акустических колебаний в химических реакциях и физико-химических процессах. Российский химический журнал. 2001.

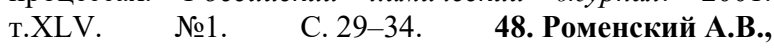
Казаков В.В., Гринь Г.И., Кунченко А.П., Волохов И.В., Лобойко А.Я. Ультразвук в гетерогенном катализе. Северодонецк: Северодонецкая городская типография, 2006. 289 с. 49. Кузнецов Д.М., Смирнов А.Н., Сыроешкин А.В. Акустическая эмиссия при фазовых превращениях в водной среде. Российский химический журнал. 2008. т.LII. №1. С. 114 121. 50. Дорофеев Б.М., Волкова В.И. Влияние статического давления на звуковые импульсы, генерируемые пузырьками пара при насыщенном кипении. Акустический журнал. 2011. т.57. №6. С. 778785. 51. Фадеев Г.Н., Болдырев В.С., Кузнецов Н.Н. Акустическая резонансная частота химических реакций. Инженерный журнал: наука и инноващии. 2013. Вып. 6. [Электронный ресурс]. Режим доступа: http://engjournal.ru/catalog/fundamentals/chem/787.html

52. Мелвин-Хьюз Э.А. Физическая химия. Т.1 М.: Издатинлит, 1962.263 с. $53 . \quad$ Ефимов А.П., 
Никонов А.В., Сапожков М.А., Шоров В.И. Акустика: Справочник. Под ред. М.А. Сапожкова. М.: Радио и связь. $\quad 1989 . \quad 336$ с. $\quad$ 54. Римский-Корсаков А.В. Електроакустика М.: «Связь», 1973. 272 с. 55. Иванов Н.И. Инженерная акустика. Теория и практика борьбы с шумами. М.: Университетская книга, Логос, 2008. 424 с. 56. Справочник проектировщика. Защита от шума в градостроительстве. Под ред. Г.Л. Осипова. М.: Стройиздат, 1993. 57. Zaporozhets O., Tokarev V. Aircraft noise modelling for environmental assessment around airports Applied Accoustics. 1998. V.55. No2. Р. 99-127. 58. Левтеров А.А., Тютюник В.В., Калугин В.Д., Ольховиков С.В. Использование эффекта акустической эмиссии при раннем обнаружении возгорания целлюлозосодержащих материалов объектовой подсистемой универсальной системы мониторинга чрезвычайных ситуаций в Украине. Прикладная радиоэлектроника. 2017. Т.16. №1-2. С. 23-40. 59. Левтеров А.А., Тютюник В.В., Калугин В.Д. Методы идентификации процесса горения целлюлозосодержащих материалов на основе эффекта акустической эмиссии. Проблемы пожарной безопасности. 2017. Вып.42. С. 72-84. 60. Левтеров О.А., Калугін В.Д., Тютюник В.В. Пат. 127254 Україна, МПК (2006) A62C 3/00, G01R 29/26 (2006.01), G08C 19/00, G08B 31/00. Спосіб раннього виявлення осередку займання. Власник патенту: Національний університет цивільного захисту України. № u201801387; заявл. 12.02.2018; опубл. 25.07.2018, бюл. № 14.

\title{
РАЗВИТИЕ НАУЧНО-ТЕХНИЧЕСКИХ ОСНОВ ОПЕРАТИВНОГО ГЕОИНФОРМАЦИОННОГО АКУСТИЧЕСКОГО МОНИТОРИНГА ИСТОЧНИКОВ ТЕРРОРИСТИЧЕСКИХ УГРОЗ
}

\author{
Игорь Викторович Рубан (доктор технических наук, профессор) ${ }^{1}$ \\ Вадим Владимирович Тютюник (доктор технических наук, с.н.с.) ${ }^{2}$ \\ Ольга Александровна Тютюник (кандидат технических наук, доцент) $)^{3}$
}

\begin{abstract}
${ }^{1}$ Харьковский национальный университет радиоэлектроники, Харьков, Украина
${ }^{2}$ Национальный университет гражданской защиты Украины, Харьков, Украина

${ }^{3}$ Харковский национальный экономический университет имени Семена Кузнеца, Харьков, Украина
\end{abstract}

С изелью развития научно-технических основ создания системы искусственного интеллекта для мониторинга террористических действий, в работе представлень результаты исследования амплитудно-частотных спектров акустической эмиссии (АЭ) процесса горения иеллюлозосодержаших материалов (как одних из основных материалов, используемых для реализаџии поджогов и нападений при организации террористических действий в виде нарушений правопорядка на локальной территории) различного физико-химического состава. Техническая реализация этого эффекта при разработке автоматизированных устройств контроля акустического пространства, как составляющих системь оперативного мониторинга за зоной террористических действий, направленная на раннее выявление источников террористических угроз для условий нормального функционирования локальной территории государства.

Ключевые слова: источники террористических угроз, террористические действия, локальная территория, процесс горения, акустическая эмиссия процесса горения, целлюлозосодержащие материаль, характерные спектры, автоматизированные устройства акустического пространства, система искусственного интеллекта, мониторинг террористических действий.

\section{DEVELOPMENT OF SCIENTIFIC AND TECHNICAL BASIS OF OPERATIONAL GEOINFORMATIONAL ACOUSTIC MONITORING OF SOURCES OF TERRORIST THREATS}

\author{
Igor Ruban (Doctor of technical sciences, Professor) ${ }^{1}$ \\ Vadym Tiutiunyk (Doctor of Technical Science, Senior Research Fellow) ${ }^{2}$ \\ Olha Tiutiunyk (Candidate of Technical Sciences, Associate Professor) ${ }^{3}$
}

\author{
${ }^{1}$ Kharkiv National University of Radio Electronics, Kharkov, Ukraine \\ ${ }^{2}$ National University of Civil Protection of Ukraine, Kharkov, Ukraine \\ ${ }^{3}$ Simon Kuznets Kharkiv National University of Economics, Kharkov, Ukraine
}

In order to develop the scientific and technical foundations of creating an artificial intelligence system for monitoring terrorist acts, the paper presents the results of a study of the amplitude-frequency spectra of acoustic emission (AE) of the combustion process of cellulose-containing materials (as one of the main materials used to carry out arson and attacks in organizing terrorist actions in the form of law and order violations in the local territory) of various physicochemical composition. The technical implementation of this effect in the development of automated devices for monitoring acoustic space as part of an operational monitoring system for the terrorist zone, aimed at early identification of the sources of terrorist threats to the normal functioning of the local territory of the state.

Keywords: the sources of terrorist threats, terrorist acts, local territory, combustion process, acoustic emission of the combustion process, cellulose-containing materials, characteristic spectra, automated acoustic space devices, artificial intelligence system, monitoring of terrorist actions. 


\section{References}

1. Tiutiunyk V.V. Systemnyi pidkhid do otsinky nebezpeky zhyttiediialnosti pry terytorialno chasovomu rozpodili enerhii dzherel nadzvychainykh sytuatsii. / V.V.Tiutiunyk, L.F. Chernogor, V.D. Kalygin // Problemy nadzvychainykh sytuatsii. Kharkiv: Natsionalnyi universytet tsyvilnoho zakhystu Ukrainy. 2011. Vyp. 14. S. 171-194. 2. Kalygin V.D. Systemnyi pidkhid do otsinky ryzykiv nadzvychainykh sytuatsii v Ukraini. / V.D. Kalygin, V.V Tiutiunyk, L.F. Chernogor, R.I. Shevchenko// Vostochno-Evropeiskyi zhurnal peredovikh tekhnolohyi. 2012. $1 / 6(55) . \quad$ S. 59-70. $\quad$ 3. Andronov V.A., Diviziniuk M.M., Kalygin V.D., Tiutiunyk V.V. (2016). Naukovo-konstruktorski osnovy stvorennia kompleksnoi systemy monitorynhu nadzvychainykh sytuatsii v Ukraini [Scientific and design basis for creating a comprehensive system for monitoring emergencies in Ukraine]. Monohrafiia. Kharkiv: Natsionalnyi universytet tsyvilnoho zakhystu Ukrainy, 319. 4. Chernogor L.F. (2012). Fizika i jekologija katastrof [Physics and ecology of catastrophes]. Har'kov: Har'kovskij nacional'nyj universitet imeni V.N. Karazina. 556. 5. Chernogor L.F. (2008). O nelinejnosti v prirode i nauke [On nonlinearity in nature and science]. Har'kov: Har'kovskij nacional'nyj universitet imeni V.N. Karazina. 528. 6. Tiutiunyk V.V. Analiz faktoriv, yaki provokuiut vynyknennia nadzvychainykh sytuatsii pryrodnoho kharakteru./ V.V Tiutiunyk, V.D. Kalygin // Systemy obrobky informatsii. Kharkiv: Kharkivskyi universytet Povitrianykh Syl imeni Ivana Kozheduba. 2011. $\begin{array}{llll}\text { Vyp.4(94). } & \text { S. 280-284. 7. Bychenok M.M., }\end{array}$ Trofymchuk O.M. (2002). Problemy pryrodnotekhnohennoi bezpeky v Ukraini [Problems of natural and technogenic safety in Ukraine]. Kyiv: RNBOU, 153. 8. Mihajlov L.A., Solomin V.P. (2008). Chrezvychajnye situacii prirodnogo, tehnogennogo i social'nogo haraktera $\mathrm{i}$ zashhita ot nih [Emergencies of natural, man-made and social nature and protection from them]. SPb.: Piter, 235. 9. On National Security of Ukraine: Law of Ukraine of 21 June 2018 № 2469-VIII Available at: http://zakon.rada.gov.ua/laws/show/2469-19.

10. Lipkan V.A. National security of Ukraine. Available at: http://westudents.com.ua/knigi/368-natsonalna-bezpekaukrani-lpkan-va.html. 11. Kodeks tsyvilnoho zakhystu Ukrainy vid 2 zhovtnia 2012 roku № 5403-VI. Voice of Ukraine. 2012. (№ 220(5470)). S. 4-20. 12. Resolution of the Cabinet of Ministers of Ukraine of January 9, 2014 № 11 "On approval of the Regulations on the Unified State System of Civil Protection". Available at: http://zakon5.rada.gov.ua/laws/show/11-2014-\%D0\%BF.

13. Order of the Cabinet of Ministers of Ukraine of January 25, 2017 № 61-r. "On approval of the Strategy for reforming the system of the Civil Service of Ukraine for Emergencies". Available at: http://zakon5.rada.gov.ua/laws/show/61-2017$\% \mathrm{D} 1 \% 80$. 14. Kalygin V.D. Rozrobka naukovotekhnichnykh osnov dlia stvorennia systemy monitorynhu, poperedzhennia ta likvidatsii nadzvychainykh sytuatsii pryrodnoho ta tekhnohennoho kharakteru ta zabezpechennia ekolohichnoi bezpeky. / V.D. Kalygin, V.V Tiutiunyk, L.F. Chernogor, R.I. Shevchenko // Systemy obrobky informatsii. Kharkiv: Kharkivskyi universytet Povitrianykh Syl imeni Ivana Kozheduba. 2013. Vyp.9(116). S. 204-216. 15. Tiutiunyk V.V. Osnovopolozhni pryntsypy stvorennia u Yedynii derzhavnii systemi tsyvilnoho zakhystu informatsiino-analitychnoi pidsystemy upravlinnia protsesamy poperedzhennia y lokalizatsii naslidkiv nadzvychainykh sytuatsii. / V.V Tiutiunyk, V.D. Kalygin, O.O. Pysklakova // Systemy upravlinnia, navihatsii ta zviazku. Poltava: Poltavskyi natsionalnyi tekhnichnyi universytet imeni Yuriia Kondratiuka. 2018. №4(50).
S. 168-177. 16. Tiutiunyk V.V. Otsinka umov stvorennia u Yedynii derzhavnii systemi tsyvilnoho zakhystu informatsiino-analitychnoi pidsystemy upravlinnia protsesamy poperedzhennia y lokalizatsii naslidkiv nadzvychainykh sytuatsii na osnovi analizu dynamiky proiavu nebezpek na terytorii Ukrainy. / V.V Tiutiunyk, V.D. Kalygin, O.O. Pysklakova // Naukove vydannia «Komunalne hospodarstvo mist. Naukovo-tekhnichnyi zbirnyk. Seriia: «Tekhnichni nauky ta arkhitektura». Kharkiv: Kharkivskyi natsionalnyi universytet miskoho hospodarstva imeni O.M. Beketova. 2019. №1(147). S. 6682. 17. On Combating Terrorism: Law of Ukraine of March 20, 2003 № 638-IV. Available at: https://zakon.rada.gov.ua/laws/show/638-15. 18. Criminal Code of Ukraine of April 5, 2001 № 2341-III. Available at: https://zakon.rada.gov.ua/laws/show/2341-14\#n1707.

19. Avdeev Ju.I. (1997). Terrorizm kak social'nopoliticheskoe javlenie. Pod red. E.I. Stepanova. M. [Terrorism as a socio-political phenomenon. Ed. E.I Stepanova. M.]. Kul'tura, 1997. 423. 20. G8 Statement on Strengthening the UN Counter-Terrorism Program. Available

http://www.krernlm.rn/mterdocs/2006/07/16/2037. 21. Responding of Defense's 1997. Annual Defense Report Available http://www.terrorism.com/terrorism/Responding. shtml. 22. Secretary General Kofi Annan's Report of 3 May 2006 "Uniting Terrorism: Recommendations for a Global Counter-Terrorism Strategy". Available at: http://www.un.org/russian/unitingagainstterrorism/report.ht ml. 23. Grachev S.I. (2007). Terrorizm. Voprosy teorii. Monografija [Terrorism. Questions of theory. Monograph]. N. Novgorod: Izd-vo NNGU im. N.I. Lobachevskogo, 269. 24. Vasil'ev N.T. Biologicheskij terrorizm: proshloe, nastojashhee, budushhee. / N.T. Vasil'ev, M.Ju. Tarasov, D.L. Poklonskij // Himicheskaja i biologicheskaja bezopasnost'. 2002. № 6. S. 3-10. 25. Tatarinov V.V. Radiacionnyj, himicheskij i biologicheskij terrorizm. / V.V. Tatarinov // Internet-zhurnal "Tehnologii tehnosfernoj bezopasnosti". 2012. Vyp.3(43) Available at: http://ipb.mos.ru/ttb. 26. Antipenko V.F. (2002). Bor'ba s sovremennym terrorizmom: mezhdunar.-pravovye podhody [The fight against modern terrorism: international legal approaches.]. Institute of State and Law. V.M. Koretsky. Kiev: Juno-M， 722. 27. Tucker J.B. (1999). Historical trends related to bioterrorism: an empirical analysis. Emerg. Infec. Disease. V.5. № 4. P. 498-504. 28. Tiutiunyk V.V. Rozrobka naukovo-tekhnichnykh osnov systemy monitorynhu zony nadzvychainoi sytuatsii, yaka vkliuchaie dostavku avtomatyzovanykh prystroiv kontroliu povitrianymy bezpilotnymy zasobamy. / V.V Tiutiunyk, V.D. Kalygin, L.F. Chernogor, R.I. Shevchenko // Nauka i tekhnika Povitrianykh Syl Zbroinykh Syl Ukrainy. Kharkiv: Kharkivskyi universytet Povitrianykh Syl imeni Ivana Kozheduba. 2014, №3(16). S. 41-44. 29. Tiutiunyk V.V. Otsinka efektyvnosti pokryttia terytorii nadzvychainoi sytuatsii za dopomohoiu avtomatyzovanykh prystroiv kontroliu nebezpechnykh faktoriv pry yikh rozkydanni iz zavysaiuchoho nad tochkoiu skydannia bezpilotnoho litalnoho aparatu. / V.V Tiutiunyk, V.D. Kalygin, H.V. Ivanets, M.H. Ivanets, Yu.V. Zakharchenko // Tekhnohenno-ekolohichna bezpeka ta tsyvilnyi zakhyst. Kyiv: Instytut heokhimii navkolyshnoho seredovyshcha NAN Ukrainy. 2016. Vyp.10. S. 34-43. 30. Ivanets H.V. Alhorytm otsinky efektyvnosti pokryttia terytorii nadzvychainoi sytuatsii avtomatyzovanymy prystroiamy kontroliu nebezpechnykh faktoriv pry yikh rozkydanni $\mathrm{z}$ bezpilotnoho litalnoho aparatu $\mathrm{v}$ umovakh nestabilnostei 
povitrianoho seredovyshcha. / H.V. Ivanets, V.V Tiutiunyk, V.D. Kalygin, B.B. Pospelov, Yu.V. Zakharchenko // Problemy nadzvychainykh sytuatsii. Kharkiv: Natsionalnyi universytet tsyvilnoho zakhystu Ukrainy. 2017. Vyp.25. S. 45-56. 31. Abduragimov I.M., Govorov V.Ju., Makarov V.E. (1980). Fiziko-himicheskie osnovy razvitija i tushenija pozharov [Physicochemical basis for the development and extinguishing of fires]. M.: VIPTSh MVD SSSR, 255. 32. Pomerancev V.V. (1986). Osnovy prakticheskoj teorii gorenija [Fundamentals of practical combustion theory]. L.: Jenergoatomizdat, 312. 33. Pozharovzryvoopasnost' veshhestv i materialov i sredstva ih tushenija. Spravochnik. Kniga 1-2. Pod red. Baratova A.N. i Korol'chenka A.Ja. (1990) [Fire and explosion hazard of substances and materials and means of their extinguishing. Directory. Book 1-2. Ed. Baratova A.N. and Korolchenko A.Ya.]. M.: Himija, 495+384. 34. Kiselev Ja.S. (2000). Fizicheskie modeli gorenija v sisteme preduprezhdenija pozharov [Physical models of combustion in the fire prevention system]. S.-P.: SPU MVD Rossii, 264. 35. Yelahin H.I., Shkarabura M.H., Kryshtal M.A., Tyshchenko O.M. (2001). Osnovy teorii rozvytku i prypynennia horinnia [Fundamentals of the theory of development and cessation of combustion]. Cherkasy: Cherkaskyi instytut pozhezhnoi bezpeky, 448. 36. Tarakhno O.V. (2006). Teoretychni osnovy pozhezhovybukhonebezpeky [Theoretical foundations of fire and explosion hazard]. Kharkiv: Academy of Civil Defense of Ukraine, 395. 37. Korol'chenko A.Ja. (2007). Processy gorenija i vzryva [Combustion and explosion processes]. M.: Pozhnauka, 266. 38. Kuskovets S.L., Shatalov O.S., Turcheniuk V.O. (2012). Osnovy teorii horinnia ta vybukhu [Fundamentals of the theory of combustion and explosion]. Rivne: Natsionalnyi universytet vodnoho hospodarstva ta pryrodokorystuvannia, 374. 39. Greshnikov V.A., Drobot Ju.B. (1976). Akusticheskaja jemissija [Acoustic emission]. M.: Izd-vo standartov, 276. 40. Eitzen D.G. Acoustic Emission: Establishing the Fundamentals. / D.G. Eitzen, H.N.G. Wadley // Journal of Research of the National Bureau of Standards. 1984. Vol.89. №1. January-February. P. 75-100. 41. Grosshandler W.L. Acoustic Emission of Structural Materials Exposed to Open Flames. /W.L. Grosshandler, M. Jackson // Fire Safety Journal. 1994. Vol.22. P. 209-228. 42. Chlenov A.N. Ul'trazvukovye ohrannye i ohranno-pozharnye izveshhateli dlja zakrytyh pomeshhenij. / A.N. Chlenov // Sistemy bezopasnosti, svjazi i telekommunikacij. mart-aprel'. M., 1999. S. 25-27. 43. Puzach S.V. Obosnovanie vozmozhnosti rannego obnaruzhenija vozgoranija v pomeshhenii s pomoshh'ju datchikov davlenija. / S.V. Puzach, Ju.A. Poljakov // Problemy bezopasnosti pri chrezvychajnyh situacijah. 1999. Vyp.3. S. 53-56. 44. Asming V.Je. Analiz infrazvukovyh signalov, generiruemyh tehnogennymi istochnikami. / V.Je. Asming, Z.A. Evtjugina, Ju.A. Vinogradov, A.V. Fedorov // Vestnik MGTU. 2009. t.12. №2. S. 300-307. 45. Klimchuk E.G. Akusticheskaja diagnostika processov «tverdofaznogo gorenija» smesej organicheskih kristallov. / E.G. Klimchuk, A.L. Parahonskij // Uchenye zapiski fizicheskogo fakul'teta.
2014. №6. S. 146322-1-146322-5. 46. Belikov V.T. Ispol'zovanie rezul'tatov nabljudenij akusticheskoj jemissii dlja izuchenija strukturnyh harakteristik tverdogo tela. / V.T. Belikov, D.G. Ryvkin //Akusticheskij zhurnal. 2015. t.61. №5. S. 622-630. 47. Smirnov A.N. Generacija akusticheskih kolebanij $\mathrm{v}$ himicheskih reakcijah i fizikohimicheskih processah. / A.N. Smirnov // Rossijskij himicheskij zhurnal. 2001. t.XLV. №1. S. 29-34. 48. Romenskij A.V., Kazakov V.V., Grin' G.I., Kunchenko A.P., Volohov I.V., Lobojko A.Ja. (2006). Ul'trazvuk $\mathrm{v}$ geterogennom katalize [Ultrasound in heterogeneous catalysis]. Severodoneck: Severodoneckaja gorodskaja tipografija, 289. 49. Kuznecov D.M. Akusticheskaja jemissija pri fazovyh prevrashhenijah $\mathrm{v}$ vodnoj srede. / D.M. Kuznecov, A.N. Smirnov, A.V. Syroeshkin // Rossijskij himicheskij zhurnal. 2008. t.LII. №1. S. 114-121.. 50. Dorofeev B.M., Volkova V.I. Vlijanie staticheskogo davlenija na zvukovye impul'sy, generiruemye puzyr'kami para pri nasyshhennom kipenii. / B.M. Dorofeev, V.I. Volkova // Akusticheskij zhurnal. 2011. t.57. №6. S. 778-785. 51. Fadeev G.N. Akusticheskaja rezonansnaja chastota himicheskih reakcij. / G.N. Fadeev, V.S. Boldyrev, N.N. Kuznecov// Inzhenernyj zhurnal: nauka i innovacii. 2013. Vyp. 6. Available at: $\mathrm{http}: / /$ engjournal.ru/catalog/fundamentals/chem/787.html

52. Melvin-H'juz Je.A. (1962). Fizicheskaja himija. T.1 [Physical chemistry. T.1]. M.: Izdatinlit, 263. 53. Efimov A.P., Nikonov A.V., Sapozhkov M.A., Shorov V.I. (1989). Akustika: Spravochnik [Acoustics: Handbook]. Pod red. M.A. Sapozhkova. M.: Radio i svjaz'. 336. 54. RimskijKorsakov A.V. (1973). Elektroakustika [Electroacoustics]. M.: «Svjaz'», 272. 55. Ivanov N.I. (2008). Inzhenernaja akustika. Teorija i praktika bor'by s shumami [Engineering acoustics. Theory and practice of noise control]. M.: Universitetskaja kniga, Logos, 424. 56. Spravochnik proektirovshhika. Zashhita ot shuma $\mathrm{v}$ gradostroitel'stve. Pod red. G.L. Osipova [Designer handbook. Noise protection in urban planning. Ed. G.L. Osipova]. M.: Strojizdat, 1993. 57. Zaporozhets O. Aircraft noise modelling for environmental assessment around airports / O. Zaporozhets, V. Tokarev //Applied Accoustics. 1998. V.55. No2. P. 99-127. 58. Levterov A.A. Ispol'zovanie jeffekta akusticheskoj jemissii pri rannem obnaruzhenii vozgoranija celljulozosoderzhashhih materialov obektovoj podsistemoj universal'noj sistemy monitoringa chrezvychajnyh situacij v Ukraine. /A.A. Levterov, V.V. Tiutiunik, V.D. Kalugin, S.V. Ol'hovikov // Prikladnaja radiojelektronika. 2017. T.16. №1-2. S. 23-40. 59. Levterov A.A. Metody identifikacii processa gorenija celljulozosoderzhashhih materialov na osnove jeffekta akusticheskoj jemissii. / A.A. Levterov, V.V. Tiutiunik, V.D. Kalugin // Problemy pozharnoj bezopasnosti. 2017. Vyp.42. S. 72-84. 60. Levterov O.A., Kaluhin V.D., Tiutiunyk V.V. Pat. 127254 Ukraina, MPK (2006) A62C 3/00, G01R 29/26 (2006.01), G08C 19/00, G08B 31/00. Sposib rannoho vyiavlennia oseredku zaimannia. Vlasnyk patentu: Natsionalnyi universytet tsyvilnoho zakhystu Ukrainy. № u201801387; zaiavl. 12.02.2018; opubl.
biul.
14. 